\section{Back to the Future? Contemporary Shifts in Australian Higher Education}

\section{Anthony Welch}

Anthony Welch is senior lecturer in the Faculty of Education, University of Sydney. Address: Faculty of Education, University of Sydney, Sydney, NSW 2006, Australia. E-mail: <a.welch@edfac.usyd.edu.au>.

S ometimes the more informal indexes of change are more $\checkmark$ telling than formal policy documents. In one of the most recent Higher Education supplements of the major national newspaper, The Australian, for example, all the lead stories on the opening page dealt with the financial aspects of privatization or commercialization of higher education. Not one story dealt with questions of staff, students, curriculum, or policy matters. ${ }^{1}$ Together with a range of other sources, this shows the extent to which the Australian system continues to change direction, toward a leaner-and arguably meaner-future.

\section{In contrast to many other nations, Australia's system of higher education is almost entirely public.}

In contrast to many other nations, Australia's system of higher education is almost entirely public. (Bond University and one or two other minor-league institutions are exceptions.) Now, however, plans are afoot to privatize significant parts of some of Australia's largest and oldest universities -including offering much higher salaries to chosen staff-while many newer, smaller, or regional universities are also working to establish or extend their private arms, either separately or in consortia. Development plans include raising the number of national and international private students, expanding commercial exploitation of intellectual property, increasing the number of Australian students who pay abnormally high fees, and creating separate private campuses of some of Australia's major universities to exploit such opportunities, thus circumventing national funding and other accountability requirements. Recent policy changes by the new conservative federal (Liberal) government, designed to allow universities to accept up to an additional 25 percent of students over the established quota, who would pay fees equivalent to those paid by international students, have fostered this greater commercialization of higher education.

This comes after a tumultuous decade of major reforms in Australian higher education-a period that has already seen substantial decreases in the proportions of university funds from the central government, a substantial relative decline in academic salaries, ${ }^{2}$ a major drop in the proportion of tenured staff between 1982 and 1991-from 81 to 61 percent, ${ }^{3}$ an increased use of casual staff, and a significant and ongoing worsening of the staff/student ratio. (It has been calculated that the average staff/student ratio has gone from around 1:11.2 in 1982, to about 1:15.5 currently, with projections that it may well reach 1:17+ within a year or two). ${ }^{4}$ Universities themselves are contributing to this worsening problem by creating significant faculty redundancies, and by overenrolling students, partly in response to the recent decision by the new federal government to refuse the funding needed to pay a long overdue salary increase for faculty. Faculty numbers increased by 36 percent over the decade 1982 to 1991, while student numbers during the same period rose by 57 percent-a mismatch that will only widen in light of intensifying funding difficulties.

Some departments and faculties within the universities have been harder hit than others. Arts and humanities faculties-including those at the larger and older institutions-have been particularly affected, with substantial losses of senior faculty and a notable absence of early career positions. Concerns are now being voiced that, unless urgent action is taken to halt this decline, it will not merely be increasingly difficult to recruit younger faculty in the future, but more established staff will be forced to move overseas as was the case in the 1950s.

\section{Increasing differentiation is also becom- ing the norm.}

Increasing differentiation is also becoming the norm. Previously, a national pay scale meant that faculty could expect the same pay at all universities. Now, not only are universities actively working to establish or defend their market niche-leading to an increasing proliferation of combined degrees-but for the first time, universities will be paying variant rates, according to different deals struck at individual institutions. Moreover, working conditions will also differ between universities as some of the deals struck in recent months involve a greater trade-off of existing working conditions, depending on, among other things, the financial state of the individual institution-some of which have gone close to breaking point. Indeed a recent study found that of Australia's 38 universities, 3 were still in deficit, while at one of the country's major institutions, the faculty of law recently voted to increase their workload 
by up to 25 percent, to eliminate several part-time posts, to cut funding for the library, and to offer more full-fee paying places in 1998 in order to cope with budget cuts. Increasing differentiation among staff from the same faculty towards senior, tenured staff (who do research) and junior, untenured staff (who are "teaching only") can also be expected to become more common.

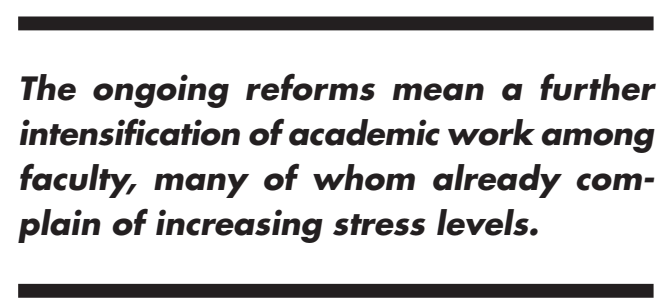

The ongoing reforms mean a further intensification of academic work among faculty, many of whom already complain of increasing stress levels. Moreover, heightening internal and external demands for greater "accountability" means that more faculty time is taken up with gathering and compiling such evidence, in addition to detailed and regular program management. Greater attention to marketing, and other such activities also takes time away from teaching and research, both of which are also subject to increasing scrutiny. All in all, fewer and fewer faculty are responding to ever more demands on a wider variety of fronts - and with lower levels of resources. It is perhaps partly for this reason that the recent U.K. Dearing Committee's analysis of comparative costs of university teaching found them to be to be lower in Australia than in any other country surveyed (the United States, the United Kingdom, Canada, Germany, and the Netherlands).

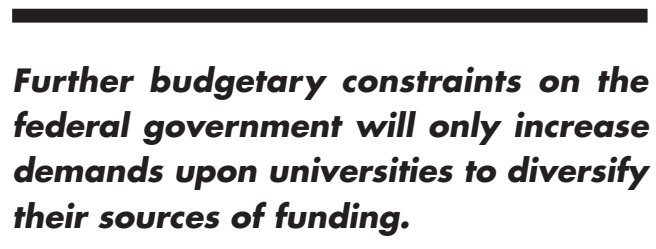

While such trends are not unique to Australia—articles in recent issues of International Higher Education point to similar trends in several other contexts-they will clearly place the Australian higher education system, and the faculty upon whom it depends for its continued health, under increasing strain. There is still no sign that current trends will soon change direction. Indeed, further budgetary constraints on the federal government will only increase demands upon universities to diversify their sources of funding. Moreover, further intensification of work can be confidently expected. Some faculty have already left to work overseas, others have taken early retirement, often without being replaced. Those who remain arguably face a challenging and troubling march "back to the future"-in which, as in the past, university entry is easier for students with wealth, and only select staff are able or, indeed, expected to maintain research activity.

\section{Notes}

1. The Australian (Higher Education supplement), September 10, 1997, 37.

2. S. Marginson, "Academic Salaries in Australia, 1967 to 1990," Australian Universities Review 2 (1989): 14-23.

3. B. Sheehan and A. Welch, The International Survey of the Academic Profession: Australia (Princeton, N.J.: Carnegie Foundation for the Advancement of Teaching, 1996), 60.

4. Department of Employment, Education and Training Higher Education Division (DEET), National Report on Australia's Higher Education Sector (Canberra: Australian Government Publishing Service, 1993), 138; see also G. Moodie, "Class Additions Don't Add Up," The Australian (Higher Education supplement), September 3, 1997, 46.

\section{Higher Education in Hong Kong: The Morning After}

\section{Gerard A. Postiglione}

Gerard A. Postiglione is senior lecturer in education at the University of Hong Kong. Address: Faculty of Education, University of Hong Kong, Pokfulam Rd., Hong Kong.

Since sovereignty retrocession, Hong Kong's universi$\checkmark$ ties have continued to transform themselves. Changes include consolidation, the introduction of a credit unit system, staff and management reviews, recurrent funding assessment, teaching and learning quality process reviews, new admission standards, an increase of students from outside of Hong Kong, staff retitling, course broadening, retrenchments, budget "top slicing," and discussion about moving from a three- to four-year system. So far, however, very little of this change seems directly tied to Beijing's control over Hong Kong. Moreover, there seems no reason why at least 3 of China's new universities in Hong Kong should not again find themselves rated among Asiaweek's top 10 Asian universities in 1998.

If the 5,000 plus academic staff in Hong Kong higher education had to operate within the standard system found on the Chinese mainland, major adaptation would be necessary to accommodate the different academic tradition, 